\title{
VIOLÊNCIA NAS MARGENS: PROSTITUIÇÃO, ABJEÇÃO E TRANS-GRESSÕES
}

\section{VIOLENCE IN THE MARGINS: PROSTITUTION, ABJECTION AND TRANS-GRESSIONS}

\author{
Paula da Luz Galrão ${ }^{1}$ \\ Paulo Dourian Pereira de Carvalho ${ }^{2}$
}

\section{RESUMO}

O presente artigo é fruto de uma pesquisa etnográfica realizada com travestis e transexuais em um ponto de prostituição na cidade de Petrolina-PE. O objetivo do estudo foi compreender os processos de violências no cotidiano de travestis e transexuais que se prostituem na cidade. Para tanto, pretendemos identificar no cotidiano das travestis e transexuais a existência e os tipos de violência mais comuns, detectar, diante de situações de violência vivenciadas por elas, os atores envolvidos no processo e entender como as travestis e transexuais agem frente a tudo isso. A partir da etnografia objetivamos entender como a vida dessas pessoas desafiam cotidianamente as normas de gênero e sexualidade, concebidas como naturais e invioláveis, e como isso as submete a situações de violência, pondo em risco as suas possibilidades de existência.

Palavras-chave: Transexuais. Travestis. Violências.

\section{ABSTRACT}

The present article is the result of an ethnographic research on transvestites and transsexuals in a prostitution point in the city of Petrolina-PE. The purpose of the study was to understand the processes of violence in the daily lives of transvestites and transsexuals who prostitutes themselves in the city. To this end, we intend to identify, in the daily lives of transvestites and transsexuals, the existence and the most common types of violence, detect, in the face of situations of violence experienced by them, the actors involved in the process and understand how travestites and transsexuals act in the face of all this. Based on ethnography, we aim to understand how the lives of these people daily challenge gender and

\footnotetext{
${ }^{1}$ Atualmente é coordenadora do KABECILÊ, Grupo de Estudos Interseccionais e é integrante da RIMAS- Rede de Integração das Mulheres Acadêmicas do Semiárido. Doutora em Ciências Sociais pela Universidade Federal da Bahia e professora do colegiado de Ciências Sociais da Universidade federal do Vale do São Francisco (UNIVASF). e-mail: paulalgalrao@gmail.com

2 Atualmente é doutorando do Programa de Pós-Graduação em Ciências Sociais da Universidade Federal do Rio Grande do Norte (UFRN). Mestre pela Universidade Federal do Rio Grande do Norte. e-mail: paulo.dourian@gmail.com
} 
sexuality norms, conceived as natural and inviolable, and how it subjects them to situations of violence, putting their possibilities of existence at risk.

Key-words: Transsexuals. Travestites. Violences.

\section{INTRODUÇÃO}

Este texto é fruto de uma pesquisa realizada com as mulheres travestis e transexuais ${ }^{3}$ de Petrolina-Pe que estão em situação de prostituição. $O$ intuito central foi compreender como o cotidiano destas mulheres é atravessado por situações de violência e como estas violências conformam suas subjetividades e expressam as relações de poder perenizadas em nossa sociedade por meio da conformação de discursos hegemônicos.

Para tanto, foram identificados no cotidiano destas mulheres a existência e os tipos de violência mais comuns, os atores envolvidos nesse processo e os significados que elas atribuem as suas vivências neste cenário em particular, assim como nas suas trajetórias de vida para além do ambiente da prostituição. Nosso olhar se voltou para as situações cotidianas de violências, para as agressões físicas e verbais, para os processos de exclusão e discriminação, para a violência psicológica e moral e para os silenciamentos (da família e do poder público municipal), a que são submetidas diariamente, e como estas violências se apresentam como uma contraofensiva social aos abalos identitários, sociais, teóricos e epistemológicos provocados pelas vivências trans.

Para elucidar estas questões, foi realizada uma pesquisa etnográfica em um ponto de prostituição da cidade de Petrolina-PE, que se localiza no centro da cidade. Associado ao método etnográfico, foi utilizado os princípios Latourianos de reagregar o social, por meio do rastreamento da rede de associações entre os agente envolvidos no cotidiano da prostituição, que são, para este autor, flexíveis e negociáveis, assim como repletos de contradições e

\footnotetext{
${ }^{3}$ Travestis e transexuais (ou apenas pessoas trans) são tomadas aqui como aquelas (es) em que a identidade de gênero não corresponde ao sexo biológico. Me utilizo dos dois termos, não optando por apenas um, uma vez que as nossas interlocutoras de campo referiam-se, a si mesmas, das duas maneiras, apesar de muitas ainda nutrirem o discurso de que o termo travesti não é bem visto porque associado à prostituição e as transexuais à cirurgia de redesignação sexual. Nesse sentido, optamos em não escolher por um dos termos, pois, como afirma Bento (2008), não se trata em definir qual das duas (travestis e transexuais) é mais mulher, uma vez que é exatamente a ideia essencializada de mulher que intentamos problematizar.
} 


\section{Revista \\ Debates Insubmissos}

incertezas. De antemão é possível afirmarmos que este rastreamento nos evidenciou não apenas a violência do cotidiano das mulheres travestis e transexuais que trabalham na prostituição em Petrolina, como, também, o "cotidiano da violência", ou seja, o modo como a violência se mostra como uma constante que baliza os modos como essas mulheres vivem, interpretam e planejam seu mundo.

A cidade de Petrolina, apesar de ter se tornado uma cidade que abriga uma Universidade Federal, uma estadual e uma municipal, com cursos e pesquisadores que têm evidenciado e discutido temáticas relativas às opressões cotidianas de populações discriminadas e marginalizadas, ainda deixa a desejar quando o assunto é compreender e/ou denunciar as vivências da população transexual e travesti da cidade. Não se verifica entre as ações e políticas efetivadas na cidade por meio da gestão municipal nenhuma que tenha como foco central a população trans. Em uma situação foi localizada uma ação relacionada a cursos de empreendedorismo, da então Secretaria da Mulher do município, voltada para as profissionais do sexo, que, por iniciativa particular da secretária, incluiu também as mulheres transexuais e travestis da cidade. Afora esta ação pontual, não se verifica nenhuma política pública consistente e perene voltada para este público. À exceção do Ambulatório Trans, que funciona em um bairro central da cidade e que tem por objetivo, segundo o único médico que atende no local, fazer o atendimento relativo à terapia hormonal desta população. A ausência do poder municipal no que se refere a esta população é tamanha que este ambulatório extrapola seus objetivos, uma vez que as mulheres travestis e transexuais da cidade utiliza-o como um posto de saúde regular. A população transexual da cidade não se sente à vontade para procurar os serviços de saúde voltados para a população mais geral, pois afirmam se sentir discriminadas pelos profissionais que sequer sabem o gênero que atribuem nos pronomes de tratamento utilizados no atendimento.

Este mal-estar nos espaços de atendimento em saúde do município apenas evidencia uma situação geral de exclusão e invisibilização em todas as outras esferas de sociabilidade da cidade. Ao caminhar pelas ruas de Petrolina não vemos as tantas mulheres trans que podemos ver à noite, nas zonas de prostituição. Elas não são vistas nas ocupações do comércio, elas, em 


\section{Revista \\ Debates Insubmissos}

sua maioria, não frequentam as escolas ou universidades, são raridade nos espaços de lazer do município. Os fluxos de trânsito destas mulheres se restringem aos poucos espaços de atuação profissional, para além da prostituição, como ou pequenos salões de beleza, por exemplo. Até participar da primeira Parada LGBT da cidade não imaginava que havia um contingente tão grande de mulheres travestis e transexuais na cidade. Neste dia me foi obvio o quanto a existência destas mulheres é cerceada e suas vidas invisibilizadas nesta cidade. A maioria das pessoas não querem saber da sua existência. E quando sabem, as querem muito longe de suas vidas.

As dificuldades de inserção no mercado de trabalho formal têm sido uma das principais formas de exclusão da população transexual e travesti no Brasil. Almeida e Vasconcellos evidenciaram o preconceito como principal obstáculo para acesso desta população ao mercado de trabalho. Os impedimentos de acesso ao trabalho formal estão relacionados ao fato de que as pessoas trans não são vistas como homens e mulheres "verdadeiros", além de serem estigmatizados por possuírem posturas sociais reprováveis pela população em geral (suposto envolvimento com drogas e prostituição). Além disso, podemos afirmar que o preconceito supera as especulações sobre os hábitos deste grupo. O problema está em encarar uma pessoa que foge do modelo "cisnormativo" (pessoas cis são aquelas em que a identidade de gênero corresponde ao sexo biológico), uma vez que para serem minimamente aceitos, a população trans precisa se portar, vestir e parecer o máximo com os homens e mulheres biológicos. Isto evidencia a aversão coletiva a tudo que não se enquadra aos padrões (ALMEIDA e VASCONCELLOS, 2018).

No que tange ao acesso à educação, por sua vez, o problema não está na falta de escola ou acesso a elas, e sim na permanência nestes espaços. No entanto, o lugar que deveria ser da inclusão, respeito e debate sobre as diferenças, se torna um espaço que exclui, ocupando o terceiro lugar, atrás da família e dos lugares públicos, como lócus de discriminação à população LGBT (TORRES, 2013), e da "engenharia de produção de corpos "normais"” (BENTO, 2008). A escola se apresenta como instituição incapaz de lidar com as diferenças, se tornando a guardiã das normas de gênero e da heterossexualidade compulsória. Neste sentido, segundo Bento, não 
podemos falar apenas de evasão. Não são as crianças e jovens que por motivos mil saem da escola. Estamos falando de uma instituição que exclui aqueles que "contaminam" o espaço escolar e que não contribuem para a reiteração das normas sociais, mesmo sendo estas normas desumanizadoras. Esta exclusão possui uma áurea de aceitabilidade dentro do ambiente escolar porque, ao patologizarmos uma identidade, categorizando-a como anormal, conferimos poder para os agentes que representam as instituições (e neste caso não apenas gestores, como também alunos) a realizar uma "assepsia" social, uma vez que o que está por trás é a ideia de uma sociedade livre de "contaminações" (BENTO, 2008).

A invisibilização das mulheres travestis e transexuais no mercado de trabalho formal, nas instituições de ensino e nos espaços de lazer em Petrolina possui um contraponto: a exposição nas zonas de prostituição. Assim como em outra cidades do Brasil, a prostituição tem sido uma das principais vias de acesso a trabalho entre as mulheres trans. Estima-se que $85 \%$ a $90 \%$ das mulheres travestis e transexuais trabalham como profissionais do sexo nas ruas das grandes cidades (SIMPSON, 2011). Apesar de o ambiente da prostituição ter sido demonstrado, por meio de pesquisas pioneiras como as de Pelúcio (2009), Kulick (2008) e Benedetti (2005), com um ambiente de trabalho como qualquer outro, sendo, inclusive um importante espaço de afirmação identitária para as mulheres trans, ainda é um local onde a violência se expressa das mais variadas formas, conformando subjetividades moldadas pela coação, pelo constrangimento, intimidações, escarnio e opressões. São nestes espaços, principalmente, onde ocorrem o espectro de violências que vitima cotidianamente a população travesti e transexual no Brasil. Os dados, apesar de alarmantes, ainda não são categorizados por iniciativa dos poderes públicos do Brasil. Há um total silenciamento das nossas instituições frente as situação de ataque aos direitos humanos da população trans, uma vez que não há uma catalogação oficial dos casos de violência contra a população transexual no Brasil. O que vemos são organizações não governamentais como o Grupo Gay da Bahia e a ANTRA (Associação Nacional de Travestis e Transexuais do Brasil) realizarem este levantamento de dados. De acordo com a ANTRA, o Brasil é campeão de assassinatos da população Trans no mundo. Segundo dossiê realizado pela ANTRA, somente em 2018, tivemos 163 casos de assassinato de pessoas transexuais no Brasil. O estado de Pernambuco não está entre os primeiro da lista, com 7 casos 
registrados em 2018, no entanto, não podemos afirmar que este ainda não seja um estado que abriga inúmeros casos de violência contra as pessoas transexuais. Apesar de Pernambuco ser um dos 6 estados do Brasil a aplicar a Lei Maria da Penha para as mulheres travestis e transexuais, ainda carecemos de dados quantitativos e qualitativos que evidenciem e discutam a situação de violência que vivem as mulheres trans nos município deste estado (assim como em todos os estados da Federação). Não há, na cidade de Petrolina-PE, qualquer estatística sobre as violências ou mortes sofridas por pessoas transgêneras. O poder público local e suas secretarias não têm relatórios sobre casos de transfobia que ocorrem na cidade

Por estarmos imersos neste cenário de violação constante de direitos, de desrespeito dos direitos humanos da população transexual e travesti no Brasil, e diante da um enorme subnotificação e precariedade de notificação dos casos de violência, é que se faz urgente que se multipliquem as pesquisas, não apenas nos grandes centros urbanos do país, onde já tem sido evidenciado pesquisas qualitativas, etnográficas e em profundidade sobre o assunto. Mas, também, nas cidades de pequeno e médio porte, onde os tentáculos do Estado, por meio de políticas públicas, demoram mais a chegar.

\section{HISTORICIZANDO CONCEITOS}

Antes de nos debruçarmos sobre o problema de pesquisa apresentado acima, precisamos, por meio de um breve histórico, compreender como o mundo ocidental passou a categorizar as identidades por meio dos pares dicotômicos masculino $\mathrm{x}$ feminino. As identidades sociais possuem um história que precisa ser desvendada para que entendamos os porquês da marginalização de determinados grupos sociais. A historicização dos processos de naturalização de categorias identitárias se fazem necessários para que compreendamos como o mundo ocidental construiu suas epistemes e visões de mundo e como estas se tornaram instrumentos eficazes para manutenção de regimes de poder que conformam um mundo baseado em territórios de normalidade circundados por uma horda de abjeções que, ao mesmo tempo que se contrapõem a este território de normalidade, também são peças fundamentais para a conformação e legitimidade da norma. 


\section{Revista \\ Debates Insubmissos}

Neste sentido, podemos constatar que, até meados do século XVII, os anatomistas trabalhavam com a concepção de que existia apenas um tipo de corpo e pelo menos dois gêneros que o habitava. A mulher era vista, fisiologicamente, como um homem invertido (Isomorfismo) (BENTO, 2008). A partir de meados do século XVIII, o discurso científico se contrapõe a este argumento, e levanta a necessidade de diferenciar, biologicamente, homens e mulheres (Dimorfismo). A partir de então houve uma multiplicação de discursos médicos para fundamentar esta diferença "natural" entre os sexos, e demonstrar, inclusive, que as diferenças sexuais tinham repercussão nos comportamentos de homens e mulheres. Os corpos, então, passaram a justificar as diferenças e hierarquias entre o masculino e o feminino e o discurso científico a respaldar a noção de que homens e mulheres são portadores de diferenças fixadas na natureza. Dessa maneira, nada se poderia contra o império da natureza. A oposição binária constituiria os sujeitos, marcando suas diferenças e identidades (BENTO, 2008). Esta definição binária estabelecida pela medicina ainda não problematizava o que hoje entendemos como gênero. Ela estabelecia, sim, o fundamento natural (o corpo sexuado) que futuramente viria a se tornar a "base imutável" deste conceito. Mas foi somente em meados do século XX que as feministas começaram a problematizar o caráter social das diferenças sexuais. Para conceituar estas diferenças, caracterizadas como sociais, as feministas cunharam o termo gênero que, diferente do sexo (referido à natureza e sua imutabilidade), era tido enquanto mutável segundo a cultura e o momento histórico, sendo definido, acima de tudo, por relações de dominação entre homens e mulheres. Este termo implicava uma rejeição ao determinismo biológico, exposto acima, enfatizando o aspecto relacional dos constructos acerca da feminilidade (SCOTT, 1994).

No entanto, diferenciar homens e mulheres segundo uma base sexual "natural" teve como consequência uma generalização das semelhanças entre mulheres (baseadas em uma biologia imutável), enfatizando somente a diferença em relação aos homens. Esta maneira de pensar dificultou as problematizações referentes às diferenças entre as mulheres, principalmente aquelas que não possuíam os atributos biológicos definidores do feminino (vagina, útero, seios) (NICHOLSON, 2000). No entanto, por este discurso histórico/crítico é possível nos contrapormos a este argumento, não afirmando que o gênero não é histórico, e sim 
que os constructos acerca do sexo biológico também são. Ao nascermos já encontramos concepções de verdade acerca do sexo, e o que podemos classificar como o normal e o patológico. Sabemos definir o que é ser homem e mulher antes de inserir o bebê na cultura. Então isto significa que já existe um saber, um discurso, médico/científico, que categoriza o normal e o patológico, o macho e a fêmea. Estes constructos pressupõem, também, uma correspondência entre sexo-gênero-desejo sexual, de modo que tudo que não se inclui neste continuo, ou rompe esta norma, é visto como patológico e anormal. Por tudo isso podemos localizar o/a transexual como um perigo para as normas de gênero, uma vez que reivindica um gênero em discordância com o corpo sexuado (BENTO, 2008). Ocupar essas zonas inóspitas, este não-lugar identitário, relega estes seres à condição de abjeção ${ }^{4}$, o que não confere a estas pessoas o status de sujeito. (BUTLER, 2000). Este lugar da abjeção se configura em sociedades que não aceitam os que não se enquadram nas normas (naturalizadas) criadas pelos seus próprios membros. Esta abjeção configura as exclusões e discriminações, que ferem os direitos humanos destes indivíduos e os relegam às esferas sociais mais marginalizadas.

Por muito tempo os saberes médicos conceberam o gênero como uma categoria diagnóstica. Eles funcionaram como o que Foucault chama de "polícia discursiva". Por décadas os saberes médicos e $\mathrm{psi}^{5}$, junto com a igreja, o direito e a política, conformaram "sociedades de discurso" que produziram verdades sobre o gênero, o sexo e o desejo sexual. Eles funcionaram como grandes edifícios que disciplinavam os discursos e distribuíam os sujeitos, ritualizaram as práticas discursivas para dominar o poder de fala. Constituíram sistemas de verdade, pautados em justificativas naturalizadas e universalizantes sobre as identidades sexuais (FOUCAULT, 2013). A medicina e as ciências psi legaram a homossexualidade ao estatuto de patologia. Hoje, o mesmo é feito com as pessoas trans, que são alocadas em categorias patologizantes, como as que as enquadram com transtornos de gênero. A incoerência entre sexo biológico e gênero cultural é tida como indicador de anormalidade e doença (BENTO, PELÚCIO, 2012).

\footnotetext{
${ }^{4}$ Apesar do conceito de abjeção ter sido forjado pela filósofa e feminista búlgaro-francesa Júlia Kristeva, ele foi apropriado e disseminado por Butler através da obra "Problemas de Gênero".

5 Psicologia, psiquiatria e psicanálise.
} 
Em 1950 diversos estudos levaram ao surgimento do "fenômeno transexual" como algo distinto da homossexualidade. O principal elemento diferenciador dessas identidades era a relação de abjeção que as pessoas trans tinham em relação aos seus órgãos genitais. Assim, para os transexuais considerados "verdadeiros" a cirurgia de transgenitalização seria o único meio de curar esses sujeitos. Neste ínterim, é elencada uma série de critérios que deveriam ser utilizados para diagnosticar o gênero do indivíduo. (BENTO, PELÚCIO, 2012).

Neste período, verificam-se conflitos entre os saberes das ciências psi e a medicina. Por um lado, as primeiras apostavam em procedimentos psicoterapêticos para tratar dos transtornos de gênero, por outro, a medicina defendia que somente a cirurgia seria eficaz nos casos de pessoas que tinham abjeção com a própria genitália. Assim, nas décadas de 1960 e 70 aumenta significativamente o número de cirurgias desta natureza (BENTO, PELÚCIO, 2012).

Segundo as autoras, em 1980 a transexualidade - transexualismo na época - entra no rol do Código Internacional de Doenças. Em seguida, foi incluído no Manual Diagnóstico e Estatístico de Transtornos Mentais, sob a nomenclatura de Transtornos de Identidade de Gênero. Tais documentos são responsáveis por direcionar as diretrizes da saúde mental em todo o mundo. Qualquer desvio da norma heterossexual e de gênero se torna passível de intervenção pelas ciências psi. Preza-se, a todo custo, pela coerência entre corpo, gênero e sexualidade, como se estes tivessem uma correspondência naturais e constituíssem a identidade do sujeito. Assim, verificamos a patologização dos comportamentos e desejos pela matriz heteronormativa que prega a estabilidade sem fissuras entre práticas sexuais, gênero, desejo e sexo genital. Se, por um lado, temos na década de 1970 a retirada do "homossexualismo" nos manuais diagnósticos, vemos, por outro, a proliferação de transtornos e desordens sexuais. A perversão dá lugar ao transtorno. A heterossexualidade aparece como a única alternativa capaz de dar sentido e inteligibilidade à vida. (BENTO, PELÚCIO, 2012).

\section{DESNATURALIZANDO OS REGIMES DE VERDADE}




\section{Revista \\ Debates Insubmissos}

Diante da multiplicidade dos discursos hegemônicos que diagnosticam e criminalizam as identidades de gênero e sexuais abjetas, surgem novos saberes sobre as sexualidades dissidentes que passam a atacar o pedestal onde se localizavam os saberes tradicionais sobre o gênero e a sexualidade. Com a construção de novos saberes, sobretudo por meio etnografias realizadas a partir dos anos 90 do século $\mathrm{XX}$, as travestis e transexuais são trazidas para os discursos das Ciências Sociais não apenas como um "sujeito travesti/transexual" uníssono, ou enquanto categorias identitárias sem fissuras ou contradições. Os corpos das pessoas trans existem enquanto artefatos inacabados, em estado de trânsito, em processo contínuo de construção e desconstrução. Essa identidade móvel nos revela, a cada dia, que os pares dicotômicos (homossexual/heterossexual, passivo/ativo, masculino/feminino) são precários para conferir sentido às experiências humanas (BENTO, 2009). As identidades sexuais e de gênero e os corpos são produções performáticas, que apesar de terem um efeito natural, original e inevitável, são efeitos de instituições, práticas e discursos amparados no falocentrismo e na heterossexualidade compulsória (BUTLER (2003).

Pensar o corpo como materialização de normas sociais rompe com o par dicotômico sexo/gênero, que, para além das consequências políticas que se refletem nas desigualdades de gênero, também reafirmam concepções de mundo pautadas na ideia de corpo vazio preenchido por um entendimento cultural que o move. Tal visão maniqueísta e teleológica tem sido superada por aquela, que considero valer a pena problematizar, que se assenta na ideia de corpo/sexo/sexualidade/gênero/cultura como um todo inteligível por todos os membros de um grupo cultural.

O corpo reitera as normas sociais por meio de performatividades que, segundo Butler, é vista como uma "prática reiterativa e citacional, pela qual o discurso produz o efeito que ele nomeia” (BUTLER, 2000, 2003). Ou seja, as normas que regulam os comportamentos sexuais trabalham de forma performativa para construir a diferença sexual a servido do imperativo sexual. Essas performances, que materializam e qualificam corpos, produzem fenômenos que regulam e constrangem comportamentos. Essas vivencias performativas criam um universo de inteligibilidade cultural que, ao passo que afirmam a norma, criam, também, todo um exterior 


\section{Revista \\ Debates Insubmissos}

que a legitima. Isso quer dizer que as performances regulatórias possibilitam identificações sexuadas ao passo que deslegitimam todas as outras que não afirmam as normas. A produção das normas regulatórias configura um domínio de seres "abjetos", que, margeando as experiências normativas, não participam do domínio dos sujeitos legítimos.

A produção de abjetos, assim, constitui o domínio dos sujeitos autorizados, mas também funciona como a zona de pressão que, atualmente mais visível e frequente, tem surgido para denunciar a suposta legitimidade natural dos constructos sociais e das relações de poder a eles inerentes. A crítica social, tornada performances subalternas, tem servido de base para deslegitimar as naturalizações das relações sociais pautadas no gênero e sexualidade e também para dar visibilidade aos modos como grandes construtores de verdades legitimam seu poder por meio da fundação de domínios que estão fora do mundo (o mundo natural). Digo fora do mundo por não haver possibilidade (nem filosófica nem factível) de um mundo para nós que não seja cultural.

Apesar de atualmente a Teoria Social, que se debruça para as questões relativas às identidades de gênero e sexuais, já terem superado as questões relativas a imutabilidade do sexo, por meio das problematizações sobre o modo como a categoria "natureza" é fundada em discursos de poder, que alocam uma esfera do mundo fora da inteligibilidade do mundo cultural, as vivências em vários espaços sociais ainda se dão à margem destas críticas. Tanto dentro como fora da academia, pessoas ainda vivem, e moldam suas relações sociais, pautadas em pares dicotômicos, que ao fim e ao cabo refletem a grande dicotomia "natureza x cultura", que reafirmam a existência de uma parte do munda fora da inteligibilidade cultural (reflexiva ou pré-reflexiva). Este princípio dicotômico, que molda a maior parte das vivências ocidentais, confere um invisibilidade extremamente daninha às propostas críticas, uma vez que supõe uma esfera do mundo social apartado das relações de poder que o molda.

Segundo os pressupostos que estamos tomando aqui, todas as categorias, que servem de lastro para nossas vivências, são históricas, logo culturais. Nenhuma delas se coloca na esfera denominada "natureza", que, pelo lugar que ocupa a partir das significações a ela atribuída, se mostra muito mais como um não-lugar no tempo e espaço, do que como outra esfera de vida. 


\section{Revista \\ Debates Insubmissos}

A problematização da categoria "natureza" como de origem também social se mostra de fundamental importância para esta crítica, uma vez que sem ela toda a crítica de gênero se mostra ineficaz por se assentar em uma categoria imutável (sexo), que homegeiniza a pluralidade das mulheres do mundo por meio de características pautadas em uma biologia supostamente natural.

O corpo e as performances trans são uma materialização evidente de como estes discursos de poder, que tem a legitimidade de construir zonas apartadas do tempo-espaço culturais, não se assentam em bases epistemológicas sólidas. As vivências trans escancaram os modos artificiosos, plásticos e fugidios que conformam as identidades sociais. Mas, acima de tudo, estas vivencias põem em xeque as zonas em que se trancam as identidades dicotômicas, nos informando que existe muito mais para além do que foi configurado enquanto feminino e masculino. Que a identidade feminina transita por códigos simbólicos que fetichizam as "mulheres de pau", que útero, ovários e vagina não definem feminilidade, que hormônios podem vir de fora pra dentro alterando corpos que ontem mesmo possuíam pelos e contornos distintos. No entanto, para além de tudo isso, as performances trans se tornam uma território, assim como uma via, extremamente fértil para redesenharmos as fronteiras de verdade que configuram o mundo ocidental. Desse modo, as vivencias trans evidenciam tanto o caráter eminentemente móvel, plástico e fugaz das identidades sociais, escancarando que a incoerência e ambiguidade são muito mais a "regra" do que a exceção, quanto também, se tornam uma peça chave para problematizarmos uma das dicotomias mais caras do mundo ocidental, a de natureza $\mathrm{x}$ cultura, jogando por terra qualquer possibilidade de concebermos a "natureza" como uma zona, uma perspectiva ou um contexto existencial.

Assim, os debates sobre as vivências trans são, ao mesmo tempo, crítica política, por evidenciar este território de seres abjetos, matáveis e violáveis; crítica teórica, por evidenciar os modos como o gênero, sexo e sexualidade são construtos sociais e históricos, escancarando as fragilidades das moralidades sociais que se amparam nestas categorias; e, também, crítica epistemológica, uma vez que põem em evidencia, critica e supera os regimes de verdade que respaldam grande parte das assertivas sobre o nosso mundo espacial/cultural, principalmente 


\section{Revista \\ Debates Insubmissos}

as relativas aos constructos dicotômicos e hierarquizados que embasam nossas narrativas. As vidas trans nos evidencia que as inteligibilidades culturais se baseiam muito mais em controvérsias e ambiguidades, que alargam as perspectivas do mundo cultural para além da simplificação do maniqueísmo conceitual, ao mesmo tempo que aniquila esta zona inabitável nomeada por natureza.

\section{METODOLOGIA}

Uma pesquisa que se pretende conhecer os processos de violências cotidianas por que passam as mulheres travestis e transexuais que se prostituem na cidade de Petrolina-PE demanda um modelo de investigação ancorado nos pressupostos da pesquisa qualitativa. Para esta averiguação, foram utilizados, fundamentalmente, a etnografia, para imersão no campo da pesquisa e a participação em conversas informais com as mulheres, no contexto da prostituição. Foi preciso que as entrevistas gravadas e até o uso do caderno de campo fossem abolidos, uma vez que o local da pesquisa e o contato com nossas interlocutoras se mostrou por demais instável, inconstante e até violento, para o uso de quaisquer outros instrumentos de pesquisa, que não a imersão etnográfica. $\mathrm{O}$ intuito da pesquisa qualitativa é aprofundar-se no mundo dos significados das ações e relações humanas, adentrar um universo não perceptível e não captável em fórmulas matemáticas e estatísticas. (MINAYO, 2008). Assim a pesquisa qualitativa é antes de tudo, compreensiva.

A opção pela etnografia se deu porque o intuito central foi investigar fatos microssociais, analisando a significação das relações sociais (LAPLANTINE, 1988). A pesquisa não se constituiu, apenas, na coleta dados, mas em impregnar-se das vivências trans, seus ideais e angústias, no contexto da prostituição e suas violências e como tudo isso configurava suas identidades. Assim, o processo etnográfico funciona como uma experiência de imersão total, possibilitando uma espécie de aculturação às avessas, em que não se compreende uma sociedade apenas em suas manifestações externas, mas em sua profundidade, nas significações que os próprios sujeitos atribuem aos seus comportamentos (LAPLANTINE, 1988)

REVISTA DEBATES INSUBMISSOS, Caruaru, PE. Brasil, Ano 3, v.3, no 9, Edição Especial. 2020. ISSN: 2595-2803 Endereço: https://periodicos.ufpe.br/revistas/debatesinsubmissos/ 


\section{Revista \\ Debates Insubmissos}

Assim como pensa Donna Haraway, as etnografias possibilitam um conhecimento situado e corporificado, um saber feito de carne e sangue, muito diferente de várias formas de conhecimentos não localizáveis e, portanto, irresponsáveis. Há grande valor em situar a nossa visão a partir da periferia e dos abismos, no terreno subterrâneo dos saberes subjugados e marginais. Contudo, sem ingenuidade, sem perder de vista que os posicionamentos dos subjugados não estão livres da crítica, da decodificação, desconstrução e reinterpretação. Em outras palavras, reconhecemos que as visões e concepções dos subjugados não figuram, necessariamente como "inocentes". Não vemos as pessoas trans como vítimas passivas frente à uma realidade hostil, pois reconhecemos o seu poder de agência, a capacidade que têm de criar estratégias para lidar com o perigo (HARAWAY, 1995).

Para a realização deste trabalho entnográfico, nos utilizamos do arcabouço teórico metodológico de Bruno Latour, uma vez que nosso foco seria estudar um agrupamento de pessoas no cenário da prostituição. De fato, para este autor, sequer podemos afirmar a existência de grupos ou agregados fechados e monolíticos. Só podemos falar de formação e grupos, associações que se configuram no fazer-se e refazer-se, uma vez que as associações se conformam enquanto um devir inconstante. Para Latour, as generalizações são feitas para racionalizar a pesquisa e torná-la mais fácil. Assim, não caberia aos sociólogos definir aquilo que existe. Isso por que, muitas vezes, ao descrever a realidade com conceitos estabelecidos, acaba-se por silenciar os atores a quem se deveria dar voz. Deste modo, seria importante para os cientistas sociais rastrear as controvérsias existentes entre os sujeitos, a fim de se chegar às conexões sociais criadas por eles mesmos, evidenciando as contradições nelas presentes. Desse modo, as ações dos sujeitos aparecem como dissipadas, mergulhadas em fluxos de associações flexíveis e negociáveis. $\mathrm{O}$ ator ou agente ${ }^{6}$, está imerso em uma rede de associações repleta de contradições e incertezas (LATOUR, 2012).

\footnotetext{
${ }^{6}$ Bruno Latour critica o humanismo clássico e propõe uma noção de agência ampla em que sejam considerados os agentes humanos e não-humanos. Assim, a existência humana não se separaria das coisas, dos objetos, máquinas...Tudo estaria entrelaçado gozando de uma agência compartilhada. Todos seriam agentes graças ao fim dos dualismos que essencializam e reduzem. Coisas que antes eram tidas como meros intermediários, isto é, forças mudas, tornam-se agente e mediadores. (LATOUR, 1994).
} 


\section{Revista \\ Debates Insubmissos}

Segundo o autor, os agrupamentos sociais, deste modo, não são ostensivos, isto é, tangíveis e facilmente identificáveis, mas performativos na medida em que se fazem através das várias formas que lhe dão existência. Esta dimensão performativa não aceita definições fechadas, pois ela não é estável ou inabalável e, assim como o social, é contingente. Por ser performativo, o grupo precisa da reprodução e do movimento para existir. Em contraposição à engenharia social proposta pela sociologia clássica, ele prioriza a negociação, o movimento e as associações de atores sociais, que estão, a todo o momento, ressignificando as suas ações.

Foi então rastreando estas conexões que a rede de mulheres trans foi se tecendo e, buscando uma primeira associação que nos levasse às mulheres travestis e transexuais do ponto de prostituição de Petrolina, que encontramos em uma (das apenas duas) aluna transexual da graduação da Universidade Federal, com campus na cidade vizinha (Juazeiro-BA ${ }^{7}$ ), que conseguimos a primeira imersão no campo. Esta aluna conhecia algumas das mulheres que se prostituíam naquela zona, e a sua intermediação foi fundamental para que conhecêssemos as interlocutoras desta pesquisa.

\subsection{As sujeitas da pesquisa}

Apresentaremos, brevemente, as principais sujeitas envolvidas nesta pesquisa ${ }^{8}$ para entendermos um pouco mais das suas vivencias e dos contextos de prostituição e violência em que estão inseridas.

Penélope autodenominou-se transexual. É uma jovem de 22 anos. Diz se prostituir por opção, pois não precisa do dinheiro, uma vez que trabalha em salões de beleza. Afirma ser muito amada pela família. Certo dia nos contou que os seus irmãos são super protetores e não

\footnotetext{
${ }^{7}$ A cidade de Juazeiro, no estado da Bahia, é vizinha a cidade de Petrolina, tendo apenas a ponte Presidente Dutra, sobre o Rio São Francisco, separando-as. É muito comum o trânsito entre as duas cidades devido à proximidade. Veremos mais adiante que muitas das nossas interlocutoras de pesquisa são residentes em Juazeiro, apesar de "fazerem ponto" em Petrolina.

${ }^{8}$ Gostaria de ressaltar que não preservamos o nome real dessas pessoas por entender que existem algumas informações comprometedoras, a exemplo do uso de drogas, assaltos e outros crimes. Porém, devo salientar que a troca dos nomes não acarretará em danos para a compreensão do trabalho.
} 


\section{Revista \\ Debates Insubmissos}

deixam qualquer pessoa lhe fazer mal. Faz programa desde os 18 anos. Toma hormônio desde a adolescência. A sua maquiagem e roupas estão sempre impecáveis. Costuma cuidar dos cabelos e da maquiagem das outras garotas. Afirma que nunca se bombou?

Viviane não quis revelar sua idade ${ }^{10}$. Diz enfaticamente ser travesti e reforça: "a transexual é aquela que corta o pinto e eu não quero cortar o meu". Viviane aparenta ter cerca de 27 anos. Tem o cabelo pintado de loiro. Afirma que não tem vergonha de se prostituir, pois “é uma profissão como qualquer outra”. Ela é muito extrovertida e fala abertamente sobre qualquer assunto. Tem a fama de ser a "mãezona" para outras trans, uma vez que costuma acolher estas últimas, sobretudo quando passam por momentos difíceis. Há cerca de dez anos atrás ela passou a cuidar de uma criança que fora abandonada pela mãe que era usuária de drogas.

Amy é uma jovem travesti que estava no ponto de prostituição nas primeiras visitas que fizemos. É muito tímida. Fala muito pouco. As informações que obtivemos dela foram oriundas de outras trans. Soubemos que estava vivendo uma situação muito difícil com sua família, pois sua mãe se casara com um homem que não aceitava o fato de ter uma enteada travesti. Então ele disse pra mãe de Amy que ela teria que escolher ou a filha ou ele. A mãe dela optou por ele e então Amy foi expulsa de casa. Foi acolhida por Viviane. Amy tinha 18 anos de idade. Mas aparentava ser mais jovem (e talvez fosse). Tomava hormônios femininos desde mais nova. Ficamos sabendo mais tarde que ela já tentara suicídio. Além disso, estava a usar muitas drogas, desde a cocaína até o crack. Depois de algumas visitas percebemos que ela não aparecia mais no ponto de prostituição. Quando perguntamos às outras meninas sobre seu paradeiro, elas disseram que ela agora estava trabalhando em Juazeiro-BA e que não morava mais com Viviane, pois estava "dando muito trabalho".

\footnotetext{
${ }^{9}$ Bombou: variação da palavra "bombar", muito comum entre pessoas trans e que significa fazer aplicação de silicone industrial no corpo. Principalmente na região dos quadris, glúteos, coxas, seios, e maxilar. A pessoa que faz a aplicação do silicone recebe o nome de bombadeira.

${ }^{10}$ Muitas mulheres s não costumam revelar a idade, sobretudo quando esta passa da casa dos vinte. As mais jovens não têm receio quanto a isso, só se forem muito novas, aí dizem ter 18, apesar de, muitas vezes, aparentar terem idade inferior.
} 


\section{Revista \\ Debates Insubmissos}

Raquel é uma jovem travesti de 18 anos. Começou a se hormonizar fazia pouco tempo. Ainda tinha muitos traços masculinos. É muito introvertida. Não costumava se abrir para nós. Nas pouquíssimas vezes em que falou, disse que seus pais aceitavam o fato dela ser travesti. Não era a única travesti da família. A sua irmã mais velha também o era. Mas Raquel fez questão de se diferenciar da irmã. Dizia que as duas eram muito diferentes. Que a sua irmã havia sido expulsa de casa porque não respeitava as normas do seu pai, não por ser travesti, mas por ser desobediente. Raquel conta: "oxe, a culpa foi dela, pois andava nua dentro de casa mostrando os peitos, chegava tarde da noite fazendo escândalo e não dava satisfação". Diferente de sua irmã mais velha, Raquel se diz obediente aos pais e respeita tudo que eles determinam.

Ruth é uma travesti de longos cabelos e 25 anos de idade. Ruth passou a morar com Viviane após a situação ficar mais difícil com sua mãe. Ela me contou que esta última é evangélica e não aceitava bem o fato de ter uma filha travesti. Ruth disse que sua mãe tinha vergonha dela e se preocupava muito com aquilo que os vizinhos e os parentes diziam. Ruth disse ter dado um basta a esta situação quando decidiu sair de casa. Apesar disso, ainda se encontra com a sua mãe, apesar de esta última não a receber mais em casa por "vergonha do que os outros vão dizer”. A mãe recebe o dinheiro que Ruth lhe entrega para ajudar no sustento da casa.

Sol é uma jovem travesti de cerca de vinte anos. É a pessoa mais alegre e desinibida entre todas as outras meninas. Sempre contou histórias engraçadíssimas das suas aventuras com seus clientes. Ela vive a vida intensamente. Fala muito palavrão e a todo o momento fala sobre sexo. Costuma dizer: "eu adoro fazer programa, gosto de rola, de macho...adoro neca ${ }^{11}$ grande". Talvez seja das travestis que mais viaja para outros estados. No ano de 2014 disse ter estado em Salvador com Penélope, mas tiveram que sair às pressas para não morrer, pois um "boy" 12, que tinha feito um programa com Penélope, tentou matá-la. Ele só não conseguiu porque Sol

\footnotetext{
${ }^{11}$ Neca: o mesmo que pênis.

12 Boy: como costumam chamar o cliente.
} 


\section{Revista \\ Debates Insubmissos}

chegou a tempo e jogou uma pedra no para-brisa do carro. Depois da confusão conseguiram fugir, mas foram juradas de morte e por isso voltaram pra Juazeiro-BA.

Samira tem cerca de 30 anos de idade. É a cafetina do ponto de prostituição. Não foi uma pessoa acessível durante a pesquisa. Só conseguimos nos aproximar um pouco dela ao final das visitas. Mas. Extremamente sagaz, estava sempre a nos observar. O que fazíamos e dizíamos não passava incólume à sua visão, embora tentasse disfarçar. Não costumava se dirigir a nós. Na maior parte do tempo tratou-nos como pessoas invisíveis. Sempre que falava não nos olhava. Mas com o tempo, já nos últimos dias de visita, deu a entender que nos aceitava no ponto.

Dona Estela não é uma travesti ou transexual. Mas mulher cisgênero, "uma racha”, como as mulheres trans do ponto costumam dizer. É o braço direito de Samira. Monitora o trabalho de todas as mulheres. Sabe de tudo que acontece no ponto de prostituição e na vida de todas as pessoas que lá trabalham. Dona Estela também faz programas, mas nos dias em que estivemos lá, só uma vez a vimos sair com um cliente. O seu principal papel é observar, saber o que as mulheres estão fazendo, se saíram para fazer programa, a fim informar à Samira caso as garotas se recusem a pagar o pedágio ${ }^{13}$ alegando não terem conseguido fazer programas. Dona Estela é uma peça chave no ponto. Ela e Samira são as pessoas mais antigas de lá.

Daniela era uma jovem travesti que conhecemos nas primeiras visitas que fizemos ao ponto de prostituição. Era muito tímida. Tinha 18 anos de idade. Era muito sorridente. Não era de falar e quando falava era pra chamar outras travestis para grelhar ${ }^{14}$. Ela era novata no ponto. Havia sido acolhida por Viviane em sua casa. Só a vimos em dois encontros. Poucos dias depois, seu corpo foi encontrado jogado dentro de um canal de irrigação na zona rural de Petrolina-PE. De acordo com a polícia, Daniela foi morta com golpes de faca. Seu corpo foi

\footnotetext{
${ }^{13}$ Pedágio se refere ao valor pago semanalmente pelas garotas de programa, trans ou mulheres cis (cisgênero), para que possam permanecer no ponto de prostituição. Trata-se de uma taxa de R $\$ 70,00$ que é paga à Samira, que se autodenomina dona do ponto, usando como justificativa o fato de ser a pessoa mais velha a fazer programa lá. Há muitas controvérsias entre as mulheres sobre o pagamento do pedágio. Muitas consideram esta cobrança absurda, embora paguem para evitar confusão. Mas não é raro elas apresentarem "desculpas" a fim de evitar tal pagamento.

${ }^{14}$ Grelhar é uma palavra muito comum no ponto. Significa fazer uso da grelha, que é o mesmo que cocaína.
} 
encontrado nu e todo perfurado. Segundo informações que obtive com as outras mulheres, os seus belos cabelos pretos haviam sido cortados.

\subsection{O Ponto de Prostituição}

A partir das $19 \mathrm{~h} 00$ as ruas do centro de Petrolina-PE começam a ficar desertas. As pessoas desaparecem e dão lugar aos carros. Nos arredores do ponto de prostituição esta situação se torna ainda mais dramática. É difícil ver pessoas passarem a pé. O local é de pouca iluminação. Há muitos usuários de drogas em volta. Também pessoas em situação de rua deitados nas calçadas. As paredes são sujas. $\mathrm{O}$ único movimento é das garotas de programa e dos veículos que passam.

O ponto de prostituição a que me refiro ocupa uma área relativamente grande, e se trata de uma "região" que é dominada pela cafetina Samira. Vizinho a ele existe outro ponto de prostituição que é dominado por outra cafetina ${ }^{15}$. As garotas de programa não podem ultrapassar as fronteiras dos seus respectivos pontos. Sendo assim, quem faz programa no ponto $A$ não pode fazer no ponto $B$ e vice-versa. Os limites de cada ponto são bem demarcados.

O ponto de Samira é um dos mais movimentados da cidade. Apesar de ficar em uma rua muito isolada, o movimento de clientes é intenso. Os clientes que procuram o serviço são de todas as idades e classes sociais. De acordo com as mulheres, o ponto é "frequentado" por clientes de todos os tipos, ricos, pobres, jovens, velhos, gordos e também por muitos casais que querem fazer sexo em grupo. ${ }^{16}$

\footnotetext{
${ }^{15}$ A cafetina "dona” do outro ponto de prostituição é Carla. Também é uma travesti.

${ }^{16}$ As mulheres deixam muito claro que detestam ser contratadas pra fazer sexo com mulheres cis. Muitas das trans não aceitam o programa, ou só concordam com a condição de não precisarem tocar nas "rachas" e nem ser tocadas por estas.
} 


\section{Revista \\ Debates Insubmissos}

A "disposição" do ponto de prostituição pode ser pensada seguinte forma. A rua principal onde fica a escadinha ${ }^{17}$ e onde Dona Estela ${ }^{18}$ costuma ficar sentada observando o movimento. É lá também onde Samira fica com maior frequência. Muitas das mulheres também gostam de fazer programa ali. Esta é uma rua com saída para todas as direções de modo que permite uma grande circulação de veículos e de garotas, que podem se deslocar rapidamente para outras ruas.

Também existe a esquina da rua, que também é um local onde as garotas costumam se concentrar quando os programas estão escassos. O fato de ficarem na esquina ajuda na visualização dos seus corpos. Inclusive, é comum a tática empregada por elas de mostrar os seios para os veículos que passam, de modo a chamar a atenção dos clientes.

Além da esquina, existe a avenida que é longa e se estende até os limites do território da cafetina Samira. No extremo oposto à esquina, nos limites do ponto de Samira é onde se concentram as garotas de programa que costumam grelhar. O local é uma praça que está sempre deserta. O único movimento é de profissionais do sexo e seus clientes. Trata-se de um local bem perigoso, segundo algumas das meninas, pois nesta praça teriam ocorrido vários crimes contra as trans.

Apesar de pagarem pedágio à Samira, as mulheres reclamam da falta de segurança no ponto de prostituição. Sobretudo em relação aos constantes assaltos. No período em que estivemos lá soubemos de muitos assaltos à mão armada. Samira não garante qualquer proteção para as mulheres que se prostituem para ela. Tivemos medo diversas vezes no ponto. A todo o momento chegavam pessoas estranhas que vinham falar com as mulheres.

Certa noite, perguntamos às mulheres o motivo de elas preferirem o ponto de prostituição de Petrolina-PE ao invés do de Juazeiro-BA, pois muitas delas moram em Juazeiro

\footnotetext{
${ }^{17}$ Escadinha: é um local onde se concentra muitas garotas. A maior parte do tempo que estivemos no ponto de prostituição, ficamos sentados com as mulheres nessa escada que fica em frente a um prédio abandonado e próximo a outras casas também abandonadas.

${ }^{18}$ Dona Estela costuma ficar sentada em uma cadeira junto com as mulheres. Sempre a conversar. As meninas costumam dizer que Dona Estela tem "uma língua solta", que adora uma fofoca, e por isso fica em um local estratégico para ver tudo que acontece. Os corpos das meninas estão literalmente sendo vigiados todo o tempo.
} 
e vem para Petrolina só para fazer programa. Se as condições de trabalho em Petrolina não eram boas, talvez do outro lado da ponte fosse melhor. Mas elas me responderam que a situação de Juazeiro é muito pior. Viviane disse que o ponto de lá não tem qualquer estrutura. O local é muito escuro, não dá pra ver nada, além disso, conta Viviane, os clientes não querem pagar motel, querem fazer o programa por lá mesmo, próximo a um terreno baldio.

Apesar de todos os problemas da vida na noite e os perigos inerentes à prostituição, notamos que o ponto de prostituição se tornou um importante ambiente de sociabilidade entre as travestis e transexuais que ali trabalham. É lá que elas encontram "pessoas como elas", com histórias de vida parecidas. No ponto elas têm suas identidades aceitas. Lá encontram companhia, se divertem, falam de bofes ${ }^{19}$, de sexo, beleza, amor, paqueras... Assim, o ponto se torna um local agradável, "em que podem fugir à solidão e aos pensamentos negativos”, como declara Viviane.

\section{PROSTITUIÇÃO E VIOLÊNCIA}

A principal estratégia em relação ao campo diz respeito ao modo como lidamos com o conceito de violência neste trabalho. A opção metodológica que escolhemos está diretamente atrelada à influência que o pensamento de Bruno Latour teve na pesquisa. Assim, nos utilizamos da perspectiva latouriana ao abordar a questão da violência com as mulheres trans, de modo que não traremos os conceitos clássicos e ocidentais de violência para aplicar à realidade das travestis e transexuais. Muito diferente disso, buscamos compreender aquilo que as nossas interlocutoras consideram ser violência.

Para a pergunta, há violência no ponto de prostituição onde ocorreu nossa pesquisa? A resposta é afirmativa. Mas quais tipos de violência? Ou melhor, quais tipos de violências segundo as concepções e vivências das travestis? É importante destacar que, durante a vivência no campo, em nenhum momento as mulheres mencionaram termos como violência psicológica, violência patrimonial, simbólica, urbana etc. As violência que elas se referiram, e de modo

\footnotetext{
19 Termo para definir homens
} 


\section{Revista \\ Debates Insubmissos}

exaustivo, foram sobretudo as violências físicas e assassinatos, as sexuais, as verbais (o escarnio, a zombaria), as coações e ameaças, a exclusão (da família, da escola e do mercado de trabalho) e as violações contra os seus próprios corpos, por meio de estratégias para tornar os contornos mais "femininos". Essas violências tinham uma diversidade de agentes: os clientes e os passantes da rua; os policiais; a cafetina; as bombadeiras e elas mesmas.

Para compreender o fenômeno da violência contra a população trans precisamos problematiza-la a luz dos debates, já inciados aqui, sobre o lugar existencial ocoupado por estes corpos, e como eles são um veículo das crítcias políticas, teóricas e epistemologicas, mencionadas acima. Para a sociedade mais ampla, travestis e transexuais têm uma sexualidade marginal e perigosa. Vivem em zonas inabitáveis, nos territórios dos desvios e das inadequações, suas existências figuram como ininteligíveis para o mundo (BUTLER 2003). Ao produzirem diferenças, esses corpos queer ${ }^{20}$ são rechaçados pela sociedade. As suas existências põem em xeque as essencializações de gênero e sexualidade. Quando uma travesti ou uma transexual sai nas ruas, ela subverte as normas sexuais defendidas pela nossa sociedade, sobretudo seus seguimentos mais conservadores.

Pessoas transgêneras nunca saem ilesas pelas subversões que provocam, pelo contrário, pagam preços altos. Na rua, são inqueridas pelos "vigilantes" da normalidade e pelos policiais de verdade. Humilhadas por xingamentos e desprezadas por todos que passam, como se fossem vidas de segunda classe, que só podem ter uma existência precária, limitada à noite, às esquinas, cujo corpo deve servir ao gozo dos homens ou como objeto de escárnio para os jovens que passam.

Travestis e transexuais são vistos, como costuma diz Butler (2003), como seres abjetos, digno de repulsa e desprezo, pois fogem à norma heterossexual que demarca o modo como o

\footnotetext{
${ }^{20} \mathrm{O}$ termo "Queer" se refere a um palavrão, um xingamento, em inglês, para se referir ao grupo de seres abjetos que se encontram à margem das identidade normativas de gênero e sexualidade. Ele foi reapropriado a partir da década de 70 do século XX pelos movimentos de coalizão e resistência ligados à questão da AIDS nos Estados Unidos. Posterior a esta apropriação, o termo Queer também foi associado às teorias críticas aos regimes de normalização, que se assentavam, fundamentalmente, nos pressupostos teóricos sobre o bio poder de Michael Foucault. Para maiores detalhes sobre a história desse termo, ver MISKOLCI, 2012.
} 
gênero e a sexualidade devem se manifestar nos corpos. A desestabilização que provocam gera violência, o desejo de seu extermínio

Curiosamente, a existência precária dessas pessoas dissidentes funciona, por outro lado, como um suporte de afirmação da heterossexualidade compulsória. O outro, considerado diferente e abjeto, é colocado em paralelo com o padrão desejável, saudável e natural. A diferença aparece como desvio, algo de valência negativa, que precisa ser eliminado ou que serve de exemplo de mau caminho, de erro, de sujeitos bestiais, sem humanidade (BENTO, 2011).

O caso mais brutal de violência no ponto de prostituição foi, sem dúvida, o assassinato de Daniela. Inicialmente Dona Estela não quis dar detalhes da morte, por medo talvez. Mas depois de alguns minutos conversando, ela começou a contar a história, já relatada anteriormente. Dona Estela disse que no dia posterior ao assassinato teve que passar a tarde toda procurando por familiares de Daniela para que pudessem reconhecer o corpo.

O ponto, desta vez, estava com um clima estranho. Era perceptível que as mulheres estavam com medo. Quando fomos falar com Sol vimos que estava muito triste, pois era amiga de Daniela e moravam juntas. Sol disse que estava desconfiada de todos os clientes, sobretudo daqueles que a chamavam para "grelhar", disse estar perturbada, vendo coisas. Mostrou-nos a foto de Daniela no celular. Contou que, antes da morte, veio um homem conversar com ela e Daniela para irem embora da cidade ou iriam morrer, pois havia uma travesti que tinha prometido matar as duas. Lembrou que o mesmo homem que saiu com Daniela naquela noite a chamou para "grelhar" e ela se recusou. Confessou que ele pretendia matar as duas de uma só vez.

Através das conversas com as mulheres descobrimos que, além das mortes consumadas, foram numerosas as tentativas de assassinato. Em uma das noites em que estávamos no ponto, Sol tinha saído para fazer um programa. Minutos depois ela voltou toda despenteada, ofegante, com as sandálias na mão. Disse que havia saído para fazer um programa com um homem. Ele a levou de carro para um local inóspito, onde havia muito mato e pouca iluminação. Sol disse para ele: "gato, por aqui não tem motel, para onde vamos?", foi aí que ele disse: "você vai para 
o inferno, pois vou te matar". Neste momento, Sol disse que pulou para cima do volante e o obrigou a parar o carro. Assim que ele parou, pegou uma faca e ela rapidamente abriu a porta e se jogou do carro. Sol conta que começou a correr e ele correu atrás dela. Foi aí que ela entrou no meio da estrada. Ao avistar o movimento de outros carros, o homem voltou pro seu veículo e fugiu. Sol quebrou seu salto, mas conseguiu salvar a sua vida. Pegou uma carona e voltou para o ponto de prostituição.

Outra tentativa de assassinato muito parecida com essa foi narrada por Viviane. Ela contou que entrou num carro de um cliente muito sério. Ele nem perguntou quanto era o programa, apenas pediu para ela entrar no veículo. Ela obedeceu. Quando chegaram a um local distante da cidade e de qualquer movimento, Viviane contou que ele mudou completamente o rosto. Fez uma cara feia e começou a dizer frases em tom áspero, uma delas foi: "esses viados têm que morrer". Viviane conta que era um homofóbico. Disse que ele sacou uma faca e tentou furá-la. Eles entraram em luta corporal dentro do carro. Viviane foi esfaqueada na perna e nos mostrou a cicatriz. Apesar de tudo, conseguiu tomar a faca dele e sair correndo. Ele fugiu e ela pegou uma carona de volta para o ponto

Além das tentativas de assassinato e assaltos, as mulheres se referem à ocorrência de muitos estupros. As histórias são muito parecidas. Chega um homem fingindo ser um cliente e chama a mulher para o programa. Ao chegarem a um local sem movimento sacam a arma, que pode ser uma faca ou um revólver, e obrigam as mulheres a fazerem sexo, sem o devido pagamento.

Viviane e Penélope contam que já conseguiram se safar de muitas tentativas de estupro. Mas, certa vez, ao saírem juntas para um programa em um caminhão, chegaram a um local ermo, e um homem puxou um facão e as obrigou a fazer sexo oral. Depois disso roubou tudo que elas tinham, inclusive a roupa, deixando-as só de calcinha. Tiveram que pegar uma carona com a polícia. Mas não prestaram qualquer queixa.

Sobre as violências verbais elas dizem que são os xingamentos, palavrões, as piadas e zombarias. Falam que isso acontece em toda parte, dentro de casa, no bairro onde moram, dentro do ônibus, no ponto onde trabalham. Raquel e Ruth dizem ser comum passarem na rua 
e ouvirem gritar palavras como: "Viado!”, "Bicha!” "Travesti do caralho!”, "Cu arrombado!”, “Doente!”, entre outras. O repertório é longo. Certo dia, quando estávamos com Sol, Penélope e Viviane no ponto, passou com uma caminhonete branca com quatro rapazes. Eles vaiavam e um deles desceu as calças e mostrou sua bunda pela janela. No momento, a situação foi cômica, mas depois Penélope disse: "tá vendo?!, é isso que precisamos enfrentar todo dia!"

O sociólogo Richard Miskolci, resgatando o sociólogo africano Stanley Cohen, utiliza o conceito de pânico moral ao se referir ao medo de desestabilização que as pessoas trans causam à sociedade. É como se as pessoas, ao se depararem com a instabilidade identitária provocada por travestis e transexuais, ficassem perdidas, com receio pela desintegração de seu mundo preto e branco. O povo, de modo geral, costuma ver as pessoas trans como uma forma de perigo, por isso estes seres desviantes são alvo de terrorismo coletivo (MILKOLCI, 2007).

Muitas mulheres dizem ser violentadas quando vão procurar empregos com carteira assinada ou mesmo quando já estão empregadas. Penélope diz que desistiu de procurar emprego em empresas, pois quando veem que ela é travesti sempre inventam alguma desculpa para não a aceitarem. Às vezes o currículo é até aceito, mas na hora da entrevista dizem que vão entrar em contato, mas nunca retornam, conta Penélope.

Algumas trans relataram que quando trabalharam em empresas os patrões exigiram que elas se vestissem como homens e que fossem chamadas pelo nome de batismo. Isso aconteceu, por exemplo, com Viviane e Penélope. Elas se referem a episódios como esse para destacar o quanto as pessoas são violentas.

Pessoas que passam por elas no ponto jogam pedra, garrafas, frutas, ovos. Estas são agressões frequentes. Além dos civis comuns que costumam passar, outro agente de violência para as trans do ponto de prostituição é a polícia. Neste sentido elas chamam a atenção para as revistas invasivas, em que são tratadas como homens e até agredidas. Penélope diz que policiais homens já tentaram revistá-la e ela não aceitou. Disse que ele não podia colocar a mão nela, pois quem deveria revistá-la é uma mulher. O policial retorquiu dizendo que ela não era mulher pra ser revistada por mulher, mas um homem vestido de mulher. 


\section{Revista \\ Debates Insubmissos}

Além disso, as mulheres contam que muitos dos policiais se aproveitam da revista que fazem para colocar as mãos em seus corpos, acariciá-las. Elas relataram que um policial, que costuma fazer programa com as mulheres, era extremamente violento e andava sempre armado. Batia nas garotas durante os programas e dizia que elas tinham que aguentar caladas, pois se não as mataria. De acordo com as mulheres, este mesmo policial costumava ir ao ponto mostrar o pênis e ameaça-las de morte. Pegava a sua arma e atirava em direção a todas elas. Elas dizem que ele "tocava o terror no ponto" 21.

Além destas, outra queixa em relação aos policiais diz respeito à omissão quando são chamados para atender alguma ocorrência. As trans relatam que, ao informarem que estão ligando do ponto de prostituição, a viatura não é enviada.

Um outro locus de violência para as mulheres trans é a família. E esta afirmação é paradoxal, pois, se por um lado a família é para algumas um lugar de acolhimento e carinho, para outras é uma instância de sofrimento. Penélope, Cris, Gisele, ${ }^{22}$ e Viviane disseram que a família é um suporte fundamental pra que a travesti não caia no mundo das drogas e da perdição. Salientam que o fato da família apoiar a travesti é fundamental para o futuro desta. Por outro lado, Thalia, Ruth, Póli ${ }^{23}$, e também Penélope e Viviane, afirmam que a família pode ser muito violenta. Muitas delas contaram que já foram agredidas pelos pais e irmãos por serem travestis. Algumas foram expulsas de casa e, em consequência disso e de outros fatores, como o preconceito na escola, foram proibidas de dar seguimento aos estudos.

Assim, para as mulheres trans, a família parece figurar como um fator determinante para a entrada no mundo da prostituição. Como fala Penélope: "quando fecham as portas de casa, abrem a janela para a noite".

\footnotetext{
${ }^{21}$ Tocar o terror: expressão para se referir ao ato de provocar pânico e medo.

${ }^{22}$ Gisele é uma transexual que não foi apresentada até então. As suas passagens pelo ponto de prostituição não eram frequentes. Cris é uma travesti com quem tivemos pouco contato. Diz ter 18 anos de idade. Ela trabalha em um ponto vizinho, por isso não a víamos com frequência.

${ }^{23}$ Thalia e Póli foram outras travestis com quem conversamos e que não tinham presença constante.
} 
Uma passagem de um texto de Berenice Bento ilustra muito bem esta frase, a socióloga diz o seguinte:

O processo de exclusão das pessoas trans começa muito cedo. Quando as famílias descobrem que o filho ou a filha está se rebelando contra a "natureza" e que desejam usar roupas e brinquedos que não são apropriados para seu gênero, o caminho encontrado para "consertá-lo" é a violência. Geralmente, entre os 13 e 16 anos as pessoas trans fogem de casa e encontram na prostituição o espaço social para sobrevivência financeira e construção de redes de sociabilidade. (BENTO, 2015, p.2).

Há outro elemento de violência que marca a relação entre algumas trans e suas famílias. É o que podemos chamar de "o mercado de aceitação". Com este conceito nos referirmos ao modo como muitas mulheres trans enxergam os interesses de familiares que se aproveitam de sua condição para lhes tirar dinheiro. Por exemplo, Viviane, Ruth e Penélope relatam que muitas famílias só "aceitam" a filha travesti se esta ajudar nas despesas de casa ou mesmo sustentar toda a família. Elas se referem a uma aceitação "de fachada" e condicionada à ajuda financeira.

É como se fosse um "mercado de aceitação" em que quanto mais a trans der dinheiro para a família, mais aceita ela será. Apesar desta aceitação, muitas vezes, significar apenas que os familiares não deixarão de falar com ela, embora a impeçam de frequentar a casa onde moram para que os "outros não vejam".

Outro importante agente de violência na concepção das mulheres é a cafetina Samira. Está última parece ser vista como um elemento opressivo. Percebemos que quando ela estava no ponto, as mulheres ficavam mais focadas em fazer programas, como se não pudessem fazer "corpo mole". Diversas vezes notei Samira cobrar o pedágio para as garotas. Em uma noite, conversando com Penélope e Raquel, elas se declararam indignadas com este pagamento. Falaram que ela não tinha direito nenhum de cobrar delas, pois a rua é pública, e Samira não tinha comprado a rua, reforçou Penélope. Raquel e Penélope contaram que muitas mulheres que não pagaram apanharam de Samira. Além de ter havido situações em que esta última teria mandado homens baterem na trans inadimplente.. 


\section{Revista \\ Debates Insubmissos}

Quando Samira estava ausente, as meninas pareciam se divertir mais, eram mais espontâneas, conversavam sem receios. Mas se Samira estivesse presente, todas focavam em fazer programas, nos clientes e esqueciam, inclusive, da nossa presença no local.

Além de todos estes agentes da violência, as travestis e transexuais do ponto de prostituição são, elas mesmas, agentes de violência. Uma destas nuances de violência se reflete na obsessão pela aparência que as faz se submeter a muitos riscos de saúde, seja colocando silicone industrial ou tomando hormônios de modo indiscriminado. $\mathrm{O}$ abuso de substâncias, como a cocaína, por muitas vezes também se configura enquanto um fator de violência contra o próprio corpo.

A preocupação excessiva com a beleza e elevação da feminilidade parecem ser uma reação e reflexo ao desprezo que recebem da sociedade que as rodeiam. É como se para serem aceitas tivessem que "se passar por mulher".

\footnotetext{
"Ser travestis" é um processo, nunca se encerra. Construir um corpo e cuidá-lo é uma das maiores preocupações das travestis. Elas estão sempre buscando a "perfeição", o que significa "passar por mulher ", uma mulher bonita e desejável, geralmente "branca" e burguesa. (PELÚCIO, 2005, p. 224)
}

Muitas delas associam a potencialização da beleza a maiores quantidades de silicone no corpo. Isto é, quanto maior a bunda, o quadril ou o seio, mais ela se destaca no ambiente de prostituição. Precisamos compreender que estes atributos físicos se tornam marcantes porque é nos espaços da rua, da prostituição, onde as mulheres trans podem "verificar" se os artifícios de feminilidade para apresentação de si encontram a reciprocidade dos outros (BENEDETTI, 2005).

No campo, percebemos muitas "escravas" de um ideal de beleza que parece ser inatingível. Todas as travestis e transexual com quem conversamos tomam hormônio indiscriminadamente. Não se importam com as doses que são ingeridas, nem sabem sobre os efeitos colaterais que a substância pode provocar no corpo. Além da hormonização, há também o uso frequente de silicone industrial.

Em uma noite, Sol contou como tinha sido a sua última bombação de silicone. Ela disse que foi em Salvador, numa bombadeira bastante conhecida por lá. Contou que comprou o 
material de silicone e levou para a travesti bombadeira fazer a aplicação. Sol disse que ficou em um quarto deitada em uma cama enquanto a bombadeira aplicava o silicone em suas coxas, bunda e quadris. Sol lembra de uma dor quase insuportável que sentiu quando o material entrava em seu corpo através de uma agulha muito grossa. Depois que a bombadeira aplicou todo o silicone fez massagens com as mãos no local para dar forma e contorno "naturais".

Sol disse que a bombadeira recomendou que ela deveria ficar alguns dias de repouso sem andar para evitar que o silicone descesse para os pés. Sol contou que não deu ouvidos à bombadeira e, no dia seguinte, já estava andando normalmente. Não foi surpresa quando Sol viu que o silicone estava descendo. Mas ela conta que só desceu um pouquinho para o seu pé, e nos mostrou. De fato, percebermos que em seu pé havia uma pequena elevação que correspondia ao silicone que desceu.

Apesar da dor e de dizer que sabe dos muitos riscos que o silicone industrial tem para a saúde, Sol diz que pretende fazer mais aplicações, pois não está satisfeita com o tamanho da sua bunda. Ela disse que deseja que fique bem maior e assim que conseguisse mais muamba ${ }^{24}$ voltaria a fazer aplicações.

Diante disso, travestis e transexuais, na ânsia de fugir da abjeção e das posições marginalizadas a que estão submetidas, acabam por buscar uma imagem branca e "glamourizada" de ser mulher. Muitas vezes, elas não desconstroem as categorias que as oprime, pelo contrário, se assujeitam às normas para se fazerem inteligíveis. Ao construírem suas identidades tomam como referencial a mulher branca, rica, famosa, loira. Essas preferências podem ser verificadas até mesmo nas escolhas dos seus nomes sociais. (MISKOLCI, PELÚCIO, 2007).

A vivência dos corpos trans, que se assujeitam às normas de beleza e feminilidade, evidenciam o modo com suas performances se expressam em controvérsias e ambiguidades, que vão para além das suas subjetividades propriamente ditas, nos sinalizando possibilidades de críticas às epistemes do mundo ocidental. Ao passo que seus corpos são a encarnação da

\footnotetext{
${ }^{24}$ Muamba: palavra usada por algumas trans para definir dinheiro.
} 


\section{nevitet

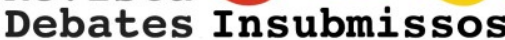

subversão às normas de gênero, evidenciam, também, o desejo pela adequação normativa, para que possam angariar um mínimo de aceitação social. No entanto, esta contradição, ao invés de anular a crítica ora proposta, de que as identidades trans são a face mais escancarada das rupturas epistemológicas, no que tange as estabilidades do sujeito e as naturalizações do mundo social, ela a reforça. As vivências trans expressas em contradições, controvérsias, incertezas e instabilidades identitárias são o reflexo mais evidente de como a estabilidade está muito longe de ser a norma. A opção por recursos simbólico normativos não indicam que essas mulheres vivem a norma. Esta opção, associada a todas que se contrapõem a ela, indicam, sim, a ruptura com os regimes de verdade que se baseavam nas naturalizações, nos maniqueísmos e na construção de estabilidade identitária.

E, assim, no rastreio das associações das vivências trans no ponto de prostituição de Petrolina, as controvérsias se fazem cotidiano. E, desse modo, a violência que praticam contra suas próprias colegas da noite se fazem constantes. Seja por inveja, ciúmes de namorados, disputas por clientes. Isso parece contribuir para tornar o ambiente da prostituição como um lugar de constante tensão. Dona Estela diz que é devido à falsidade e desunião que muitas travestis não ficam no ponto por muito tempo.

Era muito frequente ouvir as mulheres falarem que no ponto de prostituição "só tem cobra", que "ali ninguém é amiga de ninguém". Soube de casos em que travestis mandaram "rasgar" o rosto de outra, caso estivesse muito bela e feminina ${ }^{25}$. Viviane conta que a inveja impera entre elas. Diz que não há união entre elas, que uma está sempre em disputa com as outras, que praticam roubos entre si, desde itens materiais até clientes.

Um reflexo das situações de violência que vivenciam é o uso abusivo de drogas por algumas trans. É como se a substância fosse um alívio ou fuga para as agressões e violências que sofrem dentro de casa e na rua, por seus familiares, clientes, pela sociedade. Sobre o uso abusivo de drogas, afirma Pelúcio:

Esses episódios as deixam sempre em estado de alerta, prontas a reagirem, razão pela qual muitas possuem armas brancas que, por vezes, acabam sendo utilizadas contra as

\footnotetext{
${ }^{25}$ Muito semelhante a uma mulher-cis.
} 


\section{Revista \\ Debates Insubmissos}

colegas de rua. Algumas justificam que esse tipo de cotidiano as faz beber muito e se "colocar" ${ }^{26}$ - usar drogas. (PELÚCIO, 2005, p. 231)

Assim como para as travestis estudadas por Pelúcio, os tipos de drogas mais comuns utilizados pelas trans de Petrolina são o álcool e a cocaína. Esta autora percebe a relação entre o cotidiano, o sofrimento e o uso abusivo de drogas (PELÚCIO, 2005). Para Penélope e Viviane, Daniela viciou-se e já não conseguia viver sem o uso das drogas. Estava viciada em crack e cocaína. Lembro-me, nas vezes em que estivemos juntos com ela no ponto de prostituição, vê-la chamar outras meninas para "grelhar". Viviane e Penélope contam que o vício de Daniela estava tão descontrolado que ela estava fazendo sexo em troca de droga. Foi assim que ela acabou sendo assassinada, relatam Viviane e Penélope.

A banalização da violência no contexto das travestis e transexuais aparece como outro reflexo dos processos de violência que vivenciam. Era muito comum quando as mulheres relatavam casos de violência e achavam graça do episódio, como se fosse algo risível, apesar de suas vidas terem estado por um fio. Esta banalização se evidencia enquanto uma linguagem possível no ambiente da prostituição, ela se constitui como um código de valores presente nestes contextos. Esta banalização não significa, por outro lado que não há medo. Ao contrário, nestes ambientes o medo é um sentimento onipresente e necessário para modular as ações (BENEDETTI, 2005).

A presença constante de diversos tipos de violência, e de uma multiplicidade de agentes destas violências, assim como as controvérsias a estes associadas, se configuram enquanto uma constante na vida das mulheres trans. A violência do cotidiano expressa um cotidiano de violência, uma vez que o dia a dia destas mulheres é, todo ele, marcado por eventos violentos. Essa constante na vida expressa as ofensivas sociais que se bifurcam em dois sentidos que se complementam: por um lado, a violência é um reflexo de proteção à moralidade abalada por estes seres abjetos; e, por outro, é a expressão de um proteção aos regimes de verdade, e ao mundo criado por este, e aos discursos de poder que o legitimam. A violência cotidiana contra a população trans é o modus operandi de uma guerra que se utiliza tanto de facas, armas de

\footnotetext{
${ }^{26}$ As travestis de São Carlos - SP estudadas por Pelúcio (2005) usam o termo "colocar" para se referir ao uso de cocaína. Aqui as trans utilizam o termo "grelhar".
} 


\section{Revista \\ Debates Insubmissos}

fogo, palavras de escarnio e silicone industrial, como de universos simbólicos, regimes de verdade, discursos normativos e naturalizações. Essa guerra é a expressão de que não importa se nos defendemos de intifadas epistemológicas historicizando as naturalizações e expondo como os regimes de verdade são construídos por discursos de poder. Os recursos de luta mais utilizados não deixaram de ser os típicos do velho necropoder ${ }^{27}$ : o genocídio, o assassinato, a exclusão, a agressão mais bizarra e medonha, pois, afinal, para este regime maniqueísta de poder, só existe quem é bom ou mal, bonito ou feio, limpo ou sujo, e para isso só é necessário uma boa assepsia social.

\section{INCONCLUSÕES}

Seguindo a trilha de Latour, neste campo de estudo, vemos a agência como disseminada em uma teia de relações que, neste caso, envolve travestis, transexuais, policiais, cafetina, familiares, clientes, dinheiro, silicone, drogas, hormônios... Vemos que estes não-humanos assumem papéis de intermediários nos contextos das relações trans, pois a existência deles funciona como intensificadores das violências que as mulheres sofrem e praticam.

Todos estes intermediários estão em constante mudança. Por isso é difícil pensar em estabilidade neste cenário. Os posicionamentos e agenciamentos dos atores não seguem uma lógica preestabelecida. Uma trans não é só vítima, assim como um cliente nem sempre é o agressor. As agências se modificam no contexto em que as relações são estabelecidas. As performances dos atores não são cristalizadas. Mas negociadas, dissipadas, flexíveis, mergulhadas em uma rede de contradições.

Estas contradições se mostraram enquanto as violências se perpetravam e ao mesmo tempo evidenciavam os regimes de verdade e os padrões de moralidade social a estes associados. Os corpos trans se figuraram enquanto corpos matáveis e mutiláveis, na medida que expressavam um cabedal de rupturas (políticas, sociais e epistemológicas) extremamente caras aos sistema mundo ocidental. Assim, com este trabalho, tencionamos não apenas dar

\footnotetext{
${ }^{27}$ Para o aprofundamento do debate sobre Necropoder ver MBEMBE, 2018.
} 
visibilidade a essas críticas e rupturas, e apresentar um modelo de conceber as associações sociais enquanto instáveis e precárias, ao contrário dos modelos sociais que ainda se apegam a estabilidade e ordenamento das relações. Acima de tudo, intentamos dar voz e vez a este corpos invisibilizados e violados que foram colocados na margem, na intenção não de situa-los no centro e sim com o intuito de implodir todos esses locais supostamente estáveis.

\section{REFERÊNCIAS}

ALMEIDA, Cecília Barreto de; VASCONCELLOS, Victor Augusto. Transexuais: transpondo barreiras no mercado de trabalho em São Paulo? Revista Direito GV, v. 14, n. 2, p. 302-333, MAIO-AGO, 2018.

BENEDETTI, Marcos Renato. Toda feita: o corpo e o gênero das travestis. Editora Garamond, 2005, 144p.

BENEVIDES, Bruna, NOGUEIRA, Sayonara (Orgs.). Dossiê: assassinatos e violência contra travestis e transexuais n Brasil em 2018. Associação Nacional de Travestis e Transexuais do Brasil (ANTRA) Instituto Brasileiro Trans de Educação (IBTE), Brasil, 2019, 60p.

BENTO, Berenice. O que é Transexualidade. São Paulo: Brasiliense, 2008, 222p. (Coleção Primeiros Passos)

BENTO, Berenice. A diferença que faz a diferença: corpo e subjetividade na transexualidade. Bagoas, n. 04, p. 95-112, 2009.

BENTO, Berenice. Brasil: país do transfeminicídio. Clam, 2014. Disponível em: $<\mathrm{http}$ //www.clam.org.br/uploads/arquivo/Transfeminicidio_Berenice_Bento.pdf $>$, acesso em 27/06/2020.

BENTO, Berenice, PELÚCIO, Larissa. Despatologização do Gênero: a politização das identidades abjetas. Estudos feministas, v. 20, n. 2, p. 569-581, MAIO-AGO, 2012.

BUTLER, Judith. Corpos que Pesam: sobre os limites discursivos do sexo. In: LOURO, Guacira Lopes (org.). O Corpo Educado: Pedagogias da Sexualidade. Belo Horizonte: Autêntica, 2000. p. 151-172.

BUTLER, Judith. Problemas de gênero: feminismo e subversão da identidade. Editora Record, 2003, 288p. 
FOUCAULT, Michel. História da sexualidade I: a vontade de saber; tradução de Maria Thereza da Costa Albuquerque e JA Guilhon Albuquerque. Rio de Janeiro: Edições Graal, $1988,176 \mathrm{p}$

FOUCAULT, Michel. Ordem do discurso: Aula inaugural no Collège de France, pronunciada em 2 de dezembro de 1970. São Paulo: Edições Loyola, 2013, p.58

HARAWAY, Donna. Saberes localizados: a questão da ciência para o feminismo e o privilégio da perspectiva parcial. Cadernos Pagu (5), Campinas-SP, Núcleo de Estudos de Gênero - Pagu/Unicamp, 1995, pp.7-41.

KULICK, Dom. Travesti: prostituição, sexo, gênero e cultura no Brasil. Rio de Janeiro: Ed. Fiocruz, 2008, 280p.

LAPLANTINE, François. Aprender antropologia. Brasiliense, 1988, 208p.

LATOUR, Bruno Jamais fomos modernos: ensaio de antropologia simétrica. Tradução de Carlos Irineu da Costa. Rio de Janeiro: Editora 34, 1994, 152p. (Coleção Trans.)

LATOUR, Bruno. Reagregando o social: uma introdução à teoria do ator-rede. Salvador: Edufba, 2012, 400p.

MINAYO, Maria Cecília de Souza et al. Pesquisa social: teoria, método e criatividade. Petrópolis, RJ: Vozes. 2008, 80p.

MEBMBE, Achille. Necropolítica: biopoder, soberania, estado de exceção, política da morte. São Paulo: N1 Edições, 2018, 80p.

MISKOLCI, Richard; PELÚCIO, Larissa. Fora do sujeito e fora do lugar: reflexões sobre performatividade a partir de uma etnografia entre travestis. Revista Gênero, v. 7, n. 2, p. 255267, 2007.

MISKOLCI, Richard; PELÚCIO, Larissa., Teoria Queer: um aprendizado pelas diferenças. Belo Horizonte: Autêntica Editora, 2012, 78p.

NICHOLSON, Linda. Interpretando Gênero. Revista Estudos Feministas, v. 8, n. 2, 2000 PELÚCIO, Larissa. Na noite nem todos os gatos são pardos. Notas sobre a prostituição travesti. Cadernos Pagu, v. 25, p. 217-249, 2005.

PELÚCIO, Larissa. Abjeção e Desejo: uma etnografia Travesti sobre o modelo preventivo de aids. São Paulo: Annablumne; Fapesp, 2009, 262p.

SCOTT, Joan W. Prefácio a Gender and Politics of History. Cadernos Pagu, n. 3, p.11-28, 1994.

SIMPSON, Keila. Travestis: entre a atração e a aversão. In: VENTURI, Gustavo e BOKANY, 
Vilma (Orgs). Diversidade Sexual e Homofobia no Brasil. São Paulo: Editora Fundação Perseu Abramo, 2011. p. 109-117

TORRES, Marco Antonio. A diversidade Sexual na Educação e os direitos de cidadania LGBT na escola. Belo Horizonte: Autêntica Editora; Ouro Preto, MG: UFOP, 2013, 72p (Série Cadernos da Diversidade)

Submetido em: 30/06/2020

Aprovado em: 04/07/2020 